\title{
Amperometric Glucose Biosensor Based on Sol-Gel-Derived Zirconia/Nafion Composite Film as Encapsulation Matrix
}

\author{
Hyun-Jung Kim, Sook Hyun Yoon, Han Nim Choi, Young-Ku Lyu, and Won-Yong Lee* \\ Department of Chemistry and Center for Bioactive Molecular Hybrids, Yonsei University, Seoul 120-749, Korea \\ "E-mail:wvlee@yonseiackr. \\ Received October 13, 2005
}

\begin{abstract}
$\Lambda \mathrm{n}$ amperometric glucose biosensor has been developed based on the use of the nanoporous composite film of sol-gel-derived zirconia and perfluorosulfonated ionomer, Nafion, for the encapsulation of glucose oxidase (GOx) on a platinized glassy carbon electrode. Zirconium isopropoxide ( $\mathrm{ZrOPr}$ ) was used as a sol-gel precursor for the preparation of zirconia/Nafion composite film and the performance of the resulting glucose biosensor was tuned by controlling the water content in the acid-catalyzed hydrolysis of sol-gel stock solution. The presence of Nation polymer in the sol-gel-derived zirconia in the biosensor resulted in faster response time and higher sensitivity compared to those obtained at the pure zirconia- and pure Nafion-based biosensors. Because of the nanoporous nature of the composite film, the glucose biosensor based on the zirconia $\mathrm{Nation}$ composite film can reach $95 \%$ of steady-state current less than $5 \mathrm{~s}$. In addition, the biosensor responds to glucose linearly in the range of $0.03-15.08 \mathrm{mM}$ with a sensitivity of $3.40 \mu \Lambda \mathrm{mM}$ and the detection limit of $0.037 \mathrm{mM}(\mathrm{S} / \mathrm{N}=$ 3). Moreover, the biosensor exhibited good sensor-to-sensor reproducibility $(-5 \%)$ and long-term stability ( $90 \%$ of its original activity retained after 4 weeks) when stored in $50 \mathrm{mM}$ phosphate buffer at pII 7 at $4^{\circ} \mathrm{C}$.
\end{abstract}

Key Words : Glucose, Biosensor, Sol-gel technique, Zirconia/Nafion composite

\section{Introduction}

Sol-gel chemistry has gained great popularity in the field of electrochemical sensors and biosensors. ${ }^{1-9}$ Due to the inherent low temperature process, the sol-gel technology provides an attractive way for the immobilization of heatsensitive biomolecules (enzyme, protein, and antibody). In particular, sol-gel silica ( $\mathrm{SiO}_{2}$ ) possesses chemical inertness, physical rigidity, negligible swelling in aqueous solution, tunable porosity, and thermal stability. These attractive features have led to an intensive research in the electrochemical sensors and biosensors.

Although the biosensors based on the sol-gel silica exhibited improved biosensor performances compared to those based on other enzyme immobilization methods, new sol-gel materials rather than silica are still needed in order to improve further the sensitivity and stability of biosensors. Therefore, a number of different sol-gel metal oxides have been used for the construction of enzyme-based biosensors. For example, Glezer and Lev used highly conducting sol-gel vanadium pentoxide $\left(\mathrm{V}_{2} \mathrm{O}_{5}\right)$ to fabricate a highly sensitive glucose biosensor. ${ }^{10}$ Topoglidis et al. reported the immobilization of proteins (horse heart cytochrome $c$ and maltosebinding protein) on nanoporous titania $\left(\mathrm{TiO}_{2}\right)$ and $\mathrm{ZnO}$ films. ${ }^{11.12}$ The nanoporous structure of the film greatly enhances the active surface area available for protein immobilization. Yu and Ju reported glucose and hydrogen peroxide biosensors based on the porous titania sol-gel matrix prepared by a vapor deposition method. ${ }^{13,14}$ The vapor deposition method enhanced the stability of the solgel titania film. Deng research group utilized positively charged sol-gel alumina $\left(\mathrm{Al}_{2} \mathrm{O}_{3}\right)$ to develop glucose and phenol biosensors. ${ }^{15.16}$ The positively charged sol-gel alumina not only provides a friendly environment for the enzyme to retain its activity but also encapsulate a negatively charged electron transfer mediator within the solgel film by the electrostatic interaction. In all the previous reports, it is obvious that the sensitivity and stability of the biosensors can be improved by elegantly controlling the charge, porosity, and electronic conductivity of the sol-gel bioceramic films.

In this paper, we report the use of nanoporous sol-gelderived zirconia/Nafion composite film as the encapsulation matrix of glucose oxidase (GOx) on a platinized glassy carbon electrode for the development of amperometric glucose biosensor. Since zirconia $\left(\mathrm{ZrO}_{2}\right)$ is very stable and biocompatible, it has been recently used in the immobilization of enzymes for the fabrication of electrochemical biosensors. ${ }^{17.18}$ Liu $e t$ al. reported horseradish peroxidase amperometric biosensor based on a nanoporous sol-gel $\mathrm{ZrO}_{2}$ matrix on an electropolymerized thionine modified electrode..$^{17}$ Such zirconia film has a large surface area and a well-developed porosity in mesoporous range, thus providing a favorable microenvironment for enzyme immobilization. Yang $e t \mathrm{al}$. developed a surface treated nanoporous zirconia/chitosan composite film for glucose biosensor. ${ }^{18}$ Zhu et al. reported electrochemical DNA biosensor based on electrochemically deposited zirconia thin film on gold electrode.$^{19}$ Because zirconia film has affinity for phosphoric group, oligonucleotide probe can be attached to the zirconia film. ${ }^{2021}$ It is also known that sol-gel zirconia and carbon composite-modified electrode leads to a substantial decrease in the overvoltage of NADH oxidation reaction ${ }^{22}$ and also leads to an enhancement in the oxidation rate of hydro- 
quinone. ${ }^{23}$ Therefore, sol-gel zirconia is one of the most promising candidates as the immobilization matrix for biomolecules. Previously, we reported that the incorporation of Nafion in the sol-gel-derived silica and titania films minimizes the brittleness of the pure sol-gel-derived metal oxide film and also retard the shrinkage of the sol-gel films. ${ }^{24}$ Moreover, Nafion is also biocompatible with GOx enzyme as the $\mathrm{ZrO}_{2}$ film is, thus, providing substantial improvement in long-term stability of the glucose biosensor. ${ }^{25}$ In addition, the selectivity of the biosensor against several possible interfering species like ascorbic acid could be improved because the Nafion contains negativelycharged sulfonate groups, thus preventing the negativelycharged interfering species from partitioning into an electrode surface.

In the present work, we combined the advantages of both materials by using the sol-gel derived zirconia/Nafion composite film for the fabrication of glucose biosensor. We described how to tune the performance of the glucose biosensor by controlling the water content in the acidhydrolysis of sol-gel stock solution. In addition, we compared the performances of the present glucose biosensor with those of other sol-gel biosensors.

\section{Experimental Section}

Reagents. Glucose oxidase (EC 1.1.3.4, 157,500 unit/g) was obtained from Sigma Chemical Co. (St. Louis, MO, USA). Glucose was obtained from Ducksan Pure Chemical $\mathrm{Co}$. (Kyungki Do, Korea). Zirconium isopropoxide ( $\mathrm{ZrOPr}$, $99.99 \%$ ), Nafion (perfluorosulfonated ion-exchange resin, $5 \%(\mathrm{w} / \mathrm{v})$ solution in a solution of $90 \%$ aliphatic alcohol and $10 \%$ water mixture), potassium hexachloroplatinate(IV) $(99.99+\%)$, hydrogen peroxide (30 wt.\% in water), Lascorbic acid, glutamate, urea, sodium oxalate, and uric acid were obtained from Aldrich Chemical Co. (Milwaukee, WI, USA). Water for all solutions was purified using a Milli-Q water purification system (Millipore, Bedford, MA, USA). Unless otherwise noted, all chemicals were reagent grade and were used without further purification.

Instrumentation. Amperometric experiments were performed with an EG\&G 273A potentiostat (EG\&G Princeton Applied Research, Princeton, NJ, USA). All experiments were carried out with a conventional three-electrode system in a $15 \mathrm{~mL}$ electrochemical cell. The working electrode was a platinized glassy carbon $\left(0.07 \mathrm{~cm}^{2}\right)$ covered with enzymeimmobilized composite film. A platinum wire was used as the counter electrode. All the potentials quoted here were relative to an $\mathrm{Ag} / \mathrm{AgCl}(3 \mathrm{M} \mathrm{NaCl})$ reference electrode.

Preparation of Glucose Biosensor. Glassy carbon electrode was polished before each experiment with $0.05 \mu \mathrm{m} \alpha$ alumina powder, rinsed thoroughly with distilled water. The platinization of the glassy carbon was performed in $0.1 \mathrm{M}$ $\mathrm{HCl}$ solution containing $2.0 \mathrm{mM} \mathrm{PtCl}_{6}^{2-}$ by running consecutive cyclic potential scans from an initial potential 0.70 $\mathrm{V}$ to $\mathrm{a}-0.35 \mathrm{~V}$ at a scan rate of $100 \mathrm{mV} / \mathrm{s}^{26}$ The large surface area of platinized glassy carbon electrode provides higher electrocatalytic activity for $\mathrm{H}_{2} \mathrm{O}_{2}$ oxidation over conventional $\mathrm{Pt}$ disk electrode with the same geometrical area.

The sol-gel stock solution was prepared by mixing $8.0 \mathrm{~mL}$ of deionized water with $1.0 \mathrm{~mL}$ of $0.12 \mathrm{M} \mathrm{ZrOPr}$ dissolved in isopropanol and $0.25 \mathrm{~mL}$ of $11 \mathrm{M} \mathrm{HCl}$ solution in a glass vial. Once a homogeneous solution was obtained by a vigorous stirring at room temperature for $12 \mathrm{~h}$, the stock solution was stored at room temperature. The zirconia/ Nafion composite solution was prepared by mixing $1 \mathrm{~mL}$ of zirconia sol-gel stock solution with $4 \mathrm{~mL}$ of Nafion solution. Separately, a solution of GOx at $100 \mathrm{mg} / \mathrm{mL}$ was prepared in $0.05 \mathrm{M}$ phosphate buffer at $\mathrm{pH}$ 7.0. A casting solution was prepared by mixing $30 \mu \mathrm{L}$ of the zirconia/Nafion composite solution with $30 \mu \mathrm{L}$ of the enzyme solution. This resulting casting solution of $3.0 \mu \mathrm{L}$ was cast onto the surface of a platinized glassy carbon electrode and the casting solution was allowed to dry at room temperature for $5 \mathrm{~min}$. Finally, the enzyme electrode was stored in $0.05 \mathrm{M}$ phosphate buffer at $\mathrm{pH} 7.0$ for $40 \mathrm{~min}$ in order to wash out the unencapsulated GOx from the electrode surface and to swell the biosensor. When not in use, the electrode was stored in $0.05 \mathrm{M}$ phosphate buffer at $\mathrm{pH} 7$.

Experimental Conditions. Amperometric experiments were carried out in an electrochemical cell containing $10 \mathrm{~mL}$ of $0.05 \mathrm{M}$ phosphate buffer at $\mathrm{pH} 7.0$ under constant stirring. A magnetic stirrer $(270 \mathrm{rpm})$ and a stirring bar provided the convective transport in the amperometric experiments. A holding potential of $+0.5 \mathrm{~V} v s$. Ag/AgCl $(3 \mathrm{M} \mathrm{NaCl})$ was applied to the working electrode and the background current was allowed to decay to a steady state before aliquots of standard solutions of glucose were added to the electrochemical cell.

\section{Results and Discussion}

Effect of the Sol-gel Zirconia/Nafion Composition. The sol-gel preparation condition strongly affects the properties of sol-gel metal oxide gel and finally the response of the solgel-derived biosensor. In particular, the level of water employed during the acid-catalyzed sol-gel process strongly influences the porous nature of the sol-gel-derived enzyme electrodes immobilized with glucose oxidase, ${ }^{27}$ horseradish peroxidase, ${ }^{28}$ tyrosinase, ${ }^{29}$ and urease. ${ }^{30}$ Therefore, the effect of sol-gel precursor $\mathrm{ZrOPr}$ to water ratio $(\mathrm{v} / \mathrm{v})$ in the stock sol-gel solutions on the performance of the glucose biosensor based on the resulting zirconia/Nafion composite (zirconia : Nafion $=1: 4$ ) film was examined. The enzymatic reaction based on glucose oxidase is the following:

$$
\begin{aligned}
& \text { glucose }+\mathrm{O}_{2} \rightarrow \text { gluconolactone }+\mathrm{H}_{2} \mathrm{O}_{2} \\
& \mathrm{H}_{2} \mathrm{O}_{2} \rightarrow \mathrm{O}_{2}+2 \mathrm{H}^{\mathrm{t}}+2 \mathrm{e}^{-}
\end{aligned}
$$

The hydrogen peroxide is detected at the platinized glassy carbon electrode. The large surface area of platinized glassy carbon electrode results in higher electrocatalytic activity for $\mathrm{H}_{2} \mathrm{O}_{2}$ oxidation than conventional $\mathrm{Pt}$ disk electrodes with the 


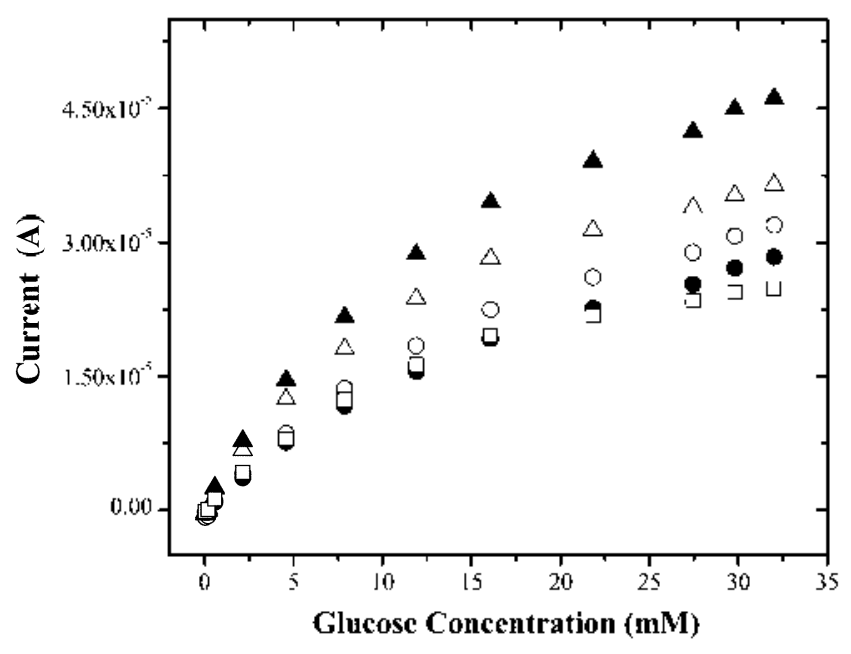

Figure 1. 1:flect of $\% \mathrm{rOP}_{\mathrm{r}}$ to $\mathrm{I}_{2} \mathrm{O}$ ratio in the stock sol-gel solution on the biosensor response. $\mathrm{ZrO}_{3}: \mathrm{H}_{2} \mathrm{O}-1: \mathrm{I}(\bullet), \mathrm{I}: 3(\mathrm{O}), \mathrm{l}: 5$ (^), $1: 8(\therefore), 1: 10(\sqcap)$. Glucose oxidase loading, $100 \mathrm{mg} / \mathrm{mL}$.

same geonetrical area. ${ }^{26}$ Figure 1 displays typical glucose calibration curves constructed with the sol-gel zirconia Nafion composite-based biosensors fabricated from different $7 \mathrm{rOPr}$ to water ratios. When the eontent of water in the solgel 7roPr stock solution increases from $1: 1$ up to $1: 5(\mathrm{v} / \mathrm{v})$, less dense and more porous sol-gel matrix was fomed, thus resulting in a faster response time (e.g. $1: 1=9.3 \mathrm{~s}, 1: 5=$ 6.7 s) and higher responses. In contrast, when the water content in the sol-gel ZrOPr stock solution is further increased, the pore size of the sol-gel matrix became even larger and the biosensor responses for $0.01 \mathrm{mM}$ glucose were rather decreased because of low enzyme loading although the response time became faster (e.g. $1: 8=4.9 \mathrm{~s}$ ) because of the increased mass transport rate in the sol-gel matrix with larger pore size. In view of the response time and sensitivity of the biosensor, the optimum $\mathrm{ZrOPr}$ to water ratio was fixed at 1:8 for all subsequent studies.

In our previous report, we found that Nafion-doped silica composite film is much more stable than the pure silica and titania films. ${ }^{24.25}$ In the present work. cation-exchange organic polymer Nafion was added into the prepared sol-gelderived $\mathrm{ZrO}_{2}$ to form organic/inorganic hybrid materials for the immobilization matrix of GOx. As shown in Table 1, the biosensor response for glucose was strongly dependent upon the volume ratio of Nafion to sol-gel metal oxide. When the $\mathrm{ZrO}_{2} / \mathrm{Nafion}$ composite film was used to construct the glucose biosensor, the sensitivities measured from the calibration curves obtained with the biosensors fabricated with all the ratios of $\mathrm{ZrO}_{2}$ to Nation in the composite films were much higher (around 2.5-3.4 $\mu \mathrm{A} / \mathrm{mM}$ ) compared to that of pure $\mathrm{ZrO}_{2}$-based $(0.1, \mathrm{l \textrm {A }} / \mathrm{mMM})$ biosensor and slightly higher than that of pure Nafion-based biosensor $(2.1 \mu \mathrm{A} /$ $\mathrm{mM})$. The maximum sensitivity of the biosensor occurs at the ratio of $1: 4$. This result indicates that an initial increase of the Nafion content in the sol-gel zirconia composite up to the ratio of $1: 4$ results in the increased activity of the $\mathrm{GOx}$ and hence the increased sensitivity. Since the organic
Table 1. Effect of sol-gel zirconium oxide $\left(\mathrm{ZrO}_{2}\right)$ sol to Nafion ratio on the biosensor response 10 glucose

\begin{tabular}{ccc}
\hline $\mathrm{ZrO}_{2}$ : Nation $(\mathrm{v}: \mathrm{v})$ & Response time $(\mathrm{s})^{h}$ & Sensitivity $(\mu \mathrm{A} / \mathrm{mM})$ \\
\hline Pure $\mathrm{ZrO}_{2}$ & 10.8 & 0.10 \\
$2: 1$ & 5.8 & 2.52 \\
$1: 1$ & 4.9 & 2.82 \\
$1: 2$ & 4.8 & 2.93 \\
$1: 4$ & 4.6 & 3.35 \\
$1: 6$ & 4.6 & 2.80 \\
Pure Nalion & 8.0 & 2.10
\end{tabular}

"Glucose oxidase loading at $100 \mathrm{~m} g / \mathrm{ml}$.; Flectrode area $=0.07 \mathrm{~cm}$ ". "Time for $95 \%$ of the steady-state eurrent for $5.0 \mathrm{mV}$. glucose.

polymer Nafion is biocompatible, ${ }^{31}$ the presenee of the Nation in the biocomposite films might be leading to the increased activity of the GOx. However, further increase in the Nation content in the composite films increases the hydrophobicity of the composite films, thus resulting the denaturation of the GOX and henee the decreased sensitivity. ${ }^{32}$

The response time to $5.0 \mathrm{mM}$ glucose was much faster with the biosensors fabricated with all the ratios of sol-gel $\mathrm{ZrO}_{2}$ to Nation in the composite (less than $6 \mathrm{~s}$ ) compared to those of both pure 7.02-based (11 s) and pure Nationbiosensor $(8 \mathrm{~s})$ as listed in Table 1 . The response time obtained witl the present biosensor is faster than the biosensor based on silica/organic polymer composite ${ }^{32}$ but slightly slower than the biosensor based on litania/ $\mathrm{Nation}$ composite $(2 \mathrm{~s}){ }^{25}$ Since the thickness of pure sol-gel $\mathrm{ZrO}_{2}$ films and composite films of $\mathrm{ZrO}_{2} \mathrm{Nafion}$ are comparable (less than $5 \mathrm{fm}$ ), the faster response time and higher sensitivity in the composite films may be mainly due to the increased pore size of the sol-gel $\mathrm{ZrO}_{2} / \mathrm{Nafion}$ composite films. The faster diffusion of substrates and products into and out of the membrane is pessible through the interconnected porous channels in the composite films. In our previous work. this kind of decreased response time in the organic/inorganic composite was also observed in the tyrosinase-immobilized sol-gel silica/Nafion composite film for phenol determination ${ }^{24}$ and glucose-oxidase-immobilized sol-gel titania/Nation composite film for glucose determination. ${ }^{25}$ For all subsequent studies, we used the optimum ratio of sol-gel metal oxide to Nafion of $1: 4$ to obtain high sensitivity and fast response time.

The morphology of the sol-gel zirconia/Nation composite film has been characterized by scanning electron microscopy (SEM). Figure 2 shows the SEM inages of the $\mathrm{ZrO}_{2} /$ Nafion $(1: 4, \mathrm{v} / \mathrm{v})$ composite film (a) and the $\mathrm{ZrO}_{2} /$ Nafion composite film doped with GOx (b). The SEM of a sol-gel $\mathrm{ZrO}_{2}$ film (not shown) displays a three-dimensional porous open structure. When the $\mathrm{ZrO}_{2}$ is mixed with the organic polymer Nafion to form zirconia/Nafion inorganic/organic hybrid composite film (Fig. 2a), the porous structure is still maintained, although the aggregates get bigger and its surfaces become smoother because of the presence of organic polymer in the composite film. When GOx was 
(a)

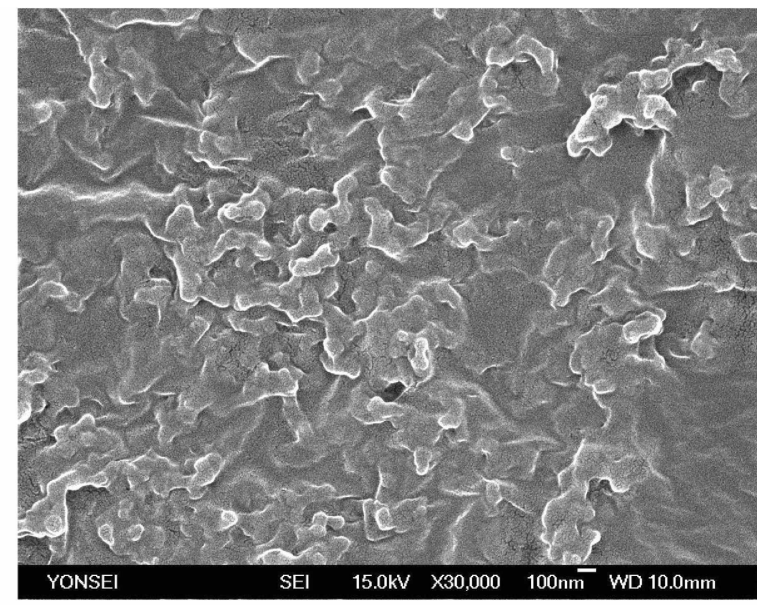

(b)

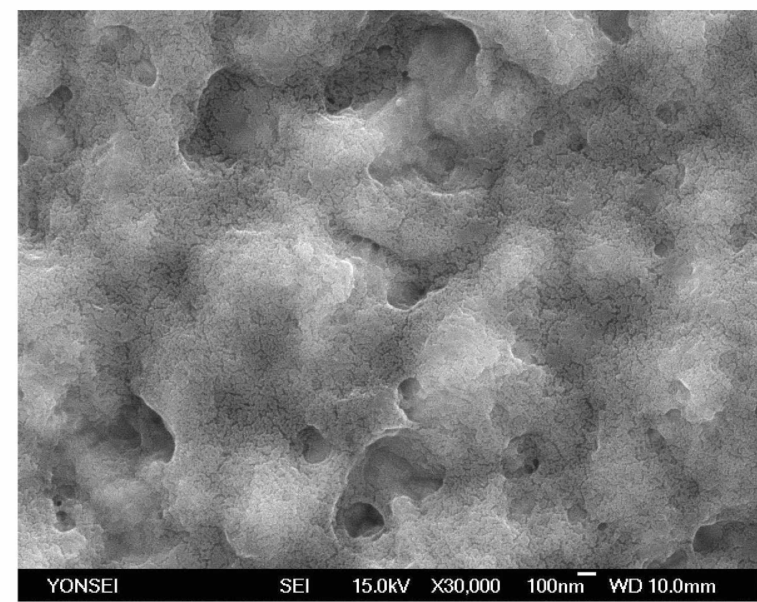

Figure 2. Scanning electron microscopy (SEM) images of the platinized glassy carbon electrode coated with a thin film of $\mathrm{ZrO}_{2} /$ Nafion (1:4) composite (a) and a thin film of $\mathrm{ZrO}_{2}$ Nafion (I : 4) composite doped with glucose oxidase $(100 \mathrm{mg} / \mathrm{mL})(\mathrm{b})$. White bar indicates $0.1 \mathrm{~mm}$ scale.

encapsulated within the $\mathrm{ZrO}_{2} / \mathrm{Nafion}$ composite matrix, island like domains of GOx were formed and regularly distributed throughout the film (Fig. 2b).

Effect of Experimental Variables. The experimental variables such as enzyme loading anount, operating potential, and $\mathrm{pH}$ were investigated in order to get optimum analytical performance of the glucose biosensor. The amount of GOx enzyme in the biosensor fabrication process strongly affects the biosensor performance in terms of sensitivity and dynamic range. Therefore, the effect of the amount of $\mathrm{GOx}$ doped into the $\mathrm{ZrO}_{2} / \mathrm{Nafion}$ composite film on the biosensor response was examined for $7.80 \mathrm{mM}$ glucose in $0.05 \mathrm{M}$ phosphate buffer at $\mathrm{pH} 7$. The rate of enzymatic oxidation, related to the biosensor response, is dependent upon the amount of the enzyme. As seen in Figure 3, the biosensor response increases as the amount of loading enzyme increases up to $100.0 \mathrm{mg} / \mathrm{mL}$, which can be converted to 61.8 units of the enzyme. However, a slight decrease in the biosensor response was observed with additional enzyme loading above $100.0 \mathrm{mg} / \mathrm{mL}$. The further increase in the amount of enzyme loading might lead to the increased

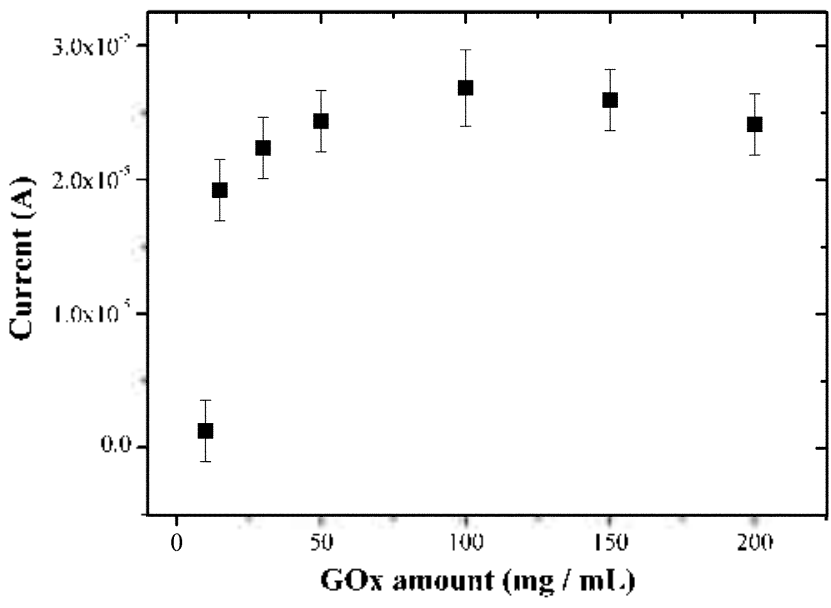

Figure 3. Effect of the amount of glucose oxidase doped into zirconia/Nation composite film on the biosensor response for 7.80 $\mathrm{mM}$ glucose in $0.05 \mathrm{M}$ phosphate bulfer at $\mathrm{pH} 7.0$. Fitor bars show standard deviation lor three differenl electrodes.

diffusional barrier for the enzymatically oxidized substrate to arrive to the electrode surface and thus decrease the biosensor response as reported in the lacease-immobilized bioclectrode. ${ }^{33}$ Therefore, an optimal kading of $100.0 \mathrm{mg} /$ $\mathrm{mL}$. was used for all subsequent experiments.

The effect of the operational potential on the biosensor response was studied over the potential range $0.2 \mathrm{~V}$ to $0.8 \mathrm{~V}$ with $1.00 \mathrm{mM}$ glucose in $0.05 \mathrm{M}$ phosphate buffer at $\mathrm{pH} 7.0$. As shown in Figure 4, the biosensor response started at 0.25 $\mathrm{V}$ ws. $\mathrm{Ag} / \mathrm{AgCl}(3 \mathrm{M} \mathrm{NaCl})$ and rapidly increased as the potential was pesitively changed from $0.3 \mathrm{~V}$ to $0.4 \mathrm{~V}$. When the potential was further changed up to $0.5 \mathrm{~V}$, the response reached a steady-state. Hydrodynamic voltammograms for $1.0 \mathrm{mM} \mathrm{H} \mathrm{H}_{2}$ were oblained at the platinized GC (PGC), purc Nalion-coaled $\mathrm{PGC}$, and zirconia/Nafion compositccoaled $\mathrm{PGC}$ electrodes in $0.05 \mathrm{M}$ phosphate bufler al $\mathrm{pH} 7$

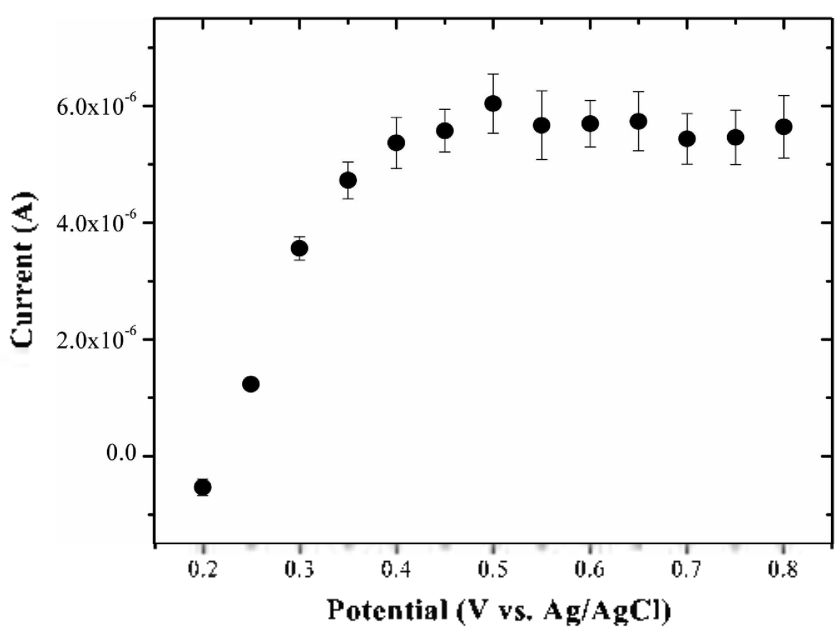

Figure 4. Iffect of operational potential ( $w . \wedge g / \wedge g C l, 3 \mathrm{M} \mathrm{NaCl}$ ) on the response of the glucose biosensor based on sol-gel zirconia Nafion composite film for $1.0 \mathrm{mM}$ glucose in $0.05 \mathrm{M}$ phosphate buffer at $\mathrm{pH} 7$. Error bars show standard deviation for three diflerent electrodes. Inzyme loading, $100 \mathrm{mg} / \mathrm{mL}$. 


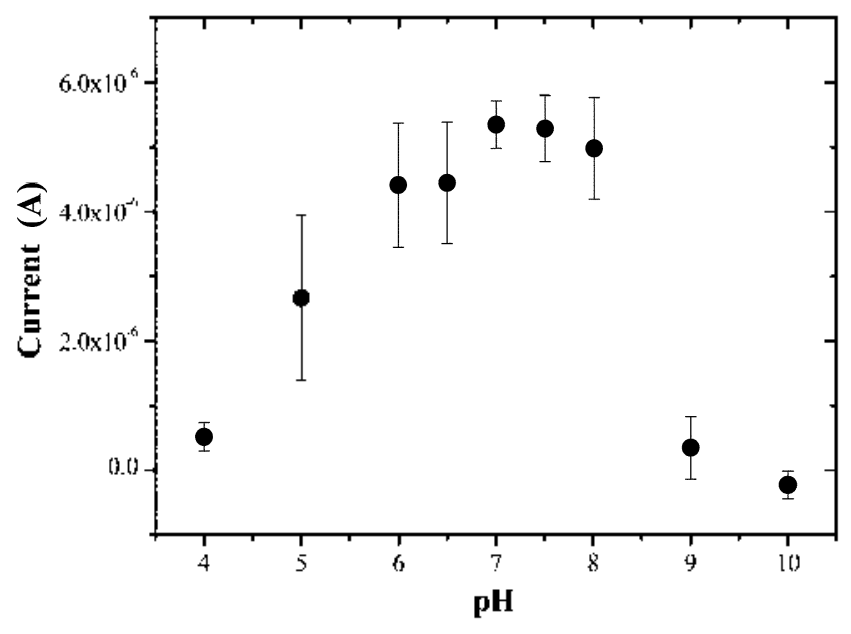

Figure 5. Effect of test solution $\mathrm{pH}$ on the response of the glucose biosensor based on sol-gel zirconia/Nafion $101.0 \mathrm{mM}$ glucose in $0.05 \mathrm{M}$ phosphate buffer. liror bars show standard deviation for three different electrodes. Operational potential, $+0.5 \mathrm{~V}$ (is $\mathrm{Ag}$ / $\mathrm{AgCl}, 3 \mathrm{M} \mathrm{NaCl}$; Enzyme loading, $100 \mathrm{mg} / \mathrm{mL}$.

(not shown). The oxidation of hydrogen peroxide in all electrodes started at $0.25 \mathrm{~V}$ and rapidly increased as the potential was positively changed from $0.3 \mathrm{~V}$ to $0.5 \mathrm{~V}$. When the potential was further changed up to $0.5 \mathrm{~V}$, the response reached a steady-state. The coincidenee of the starting potential in the present biosensor and the oxidation potential of hydrogen peroxide in the PGC electrode strongly supports that the hydrogen peroxide is being detected in the biosensor. Finally, a potential of $0.5 \mathrm{~V}$ was selected as an optimum polential for all subsequent experiments.

Since the enzyme activity is strongly aflected by the solution $\mathrm{pH}$, the effect of $\mathrm{pH}$ on the biosensor response was examined with $1.0 \mathrm{mM}$ glucose in $0.05 \mathrm{M}$ phosphate buffer. As seen in Figure 5, the highest response of the biosensor based on the $\mathrm{ZrO}_{2} / \mathrm{Nalion}$ composite film oceurs at $\mathrm{pH} 7.0$, which is similar result observed for other sol-gel immobilized glucose biosensors. We used the buffer solution of $\mathrm{pH} 7.0$ throughout the experiments to obtain the maximum sensitivity.

Characteristics of the Biosensor. Using the optimum conditions obtained in the above studies, calibration curves of the amperometric glucose biosensors based on the $\mathrm{ZrO}_{2} /$ Nafion ( $1: 4)$ composite film has been constructed. As shown in Figure 6 , the biosensor based on the zirconia/ Nafion responds linearly up to $15.08 \mathrm{mM}$ with a correlation coefficient of 0.996 , with a detection limit of $0.037 \mathrm{mM}(\mathrm{S} /$ $\mathrm{N}=3$ ). The linear response obtained with the present biosensor in a range $0.03-15.08 \mathrm{mM}$ covers the clinical region for a range of 3.5-6.5 $\mathrm{mM}$ glucose. ${ }^{34}$

The sensitivity of the present biosensor based on the $\mathrm{ZrO}_{2}$ Nafion is determined to be $3.40 \mu \mathrm{A} / \mathrm{mM}$, which is two orders of magnitude higher than that of the sol-gel $\mathrm{ZrO}_{2} /$ chitosan composite film $(0.028, \mu \mathrm{A} / \mathrm{mM}){ }^{18}$ and slightly better than those of the sol-gel $\mathrm{TiO}_{2} /$ copolymer composite film $^{35}$ and the sol-gel silica carbon composite film. ${ }^{27}$ The high sensitivity of the biosensor can be attributed to the good

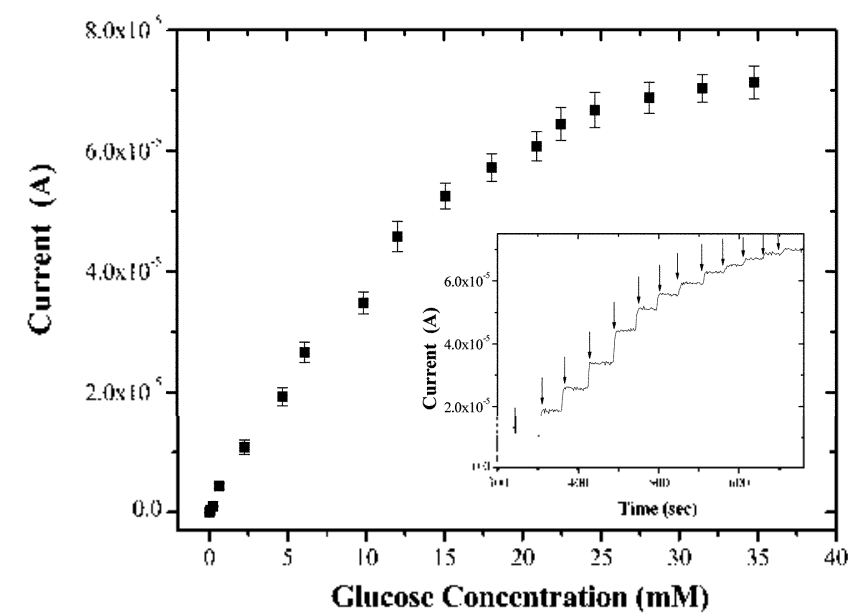

Figure 6. Calibration curves of the glucose biosensor based on zirconia/Nation composite films in aerated $0.05 \mathrm{M}$ phosphate buffer at $\mathrm{pH} 7$ under constant stirting. Inset shows typical currentlime responses of the biosensor based on zirconiad $\mathrm{Nafion}$ composite film. Error bars show standard deviation for three different electrodes. Operational potential, $+0.5 \mathrm{~V}(1 . \mathrm{Ag} / \mathrm{AgCl}, 3$ $\mathrm{M} \mathrm{NaCl}$ ); Enzyme loading, $100 \mathrm{mg} / \mathrm{mL}$.

biocompatible microenvironment around the enzyme and the porous nature of the sol-gel zirconium oxide/Nafion composite film. However, the sensitivity of the present biosensor is slightly lower than the corresponding $\mathrm{TiO}_{2} / \mathrm{Nation}$ composite film, ${ }^{25}$ This indicates that the sol-gel titania could provide more friendly environment for the GOx enzyme than the zirconia.

The apparent Michaclis-Menten constant $\left(K_{m}\right)$, calculated from the calibration plot using Lineweaver-Bulk plot $(1 / \mathrm{i} v \mathrm{~s}$ $1 /$ cone.), ${ }^{36}$ gives an indication of the enzyme-substrate kineties for the enzyme electrode. The $K_{\text {m }}$ value for the present glucose biosensor based on the zirconia/ $/$ adion composite film was found to be $9.3 \mathrm{mM}$. The $K_{m}$ value determined with the present glucose biosensor was smaller than those obtained with the biosensors based on both pure $\mathrm{ZrO}_{2}$ film $(20 \mathrm{mM})$ and the previously reported pure sol-gel silica film $(50 \mathrm{mM})^{37}$ and screen-printed sol-gel silica carbon composite $(38 \mathrm{mM}){ }^{38}$ The smaller $K_{\mathrm{m}}$ values indicates that the diffusion of substrate and product into and out of the membrane is slightly easier in the present $\mathrm{ZrO}_{2} / \mathrm{Nafion}$ composite matrix rather than in the pure sol-gel silica matrix. In our previous work, this kind of decreased $K_{m}$ value in the organic/inorganic composite film was also observed in the glucose biosensors based on both silica/ Nafion and titania/Nafion composite films. ${ }^{25}$

The biosensor-to-biosensor reproducibility was examined by measuring the responses of 9 replicate biosensors, fabricated independently, to $1.0 \mathrm{mM}$ glucose. The relative standard deviation of $-5 \%$ was observed in the biosensor based on the zirconia/Nafion composite film.

The selectivity of the present glucose biosensor against several possible interfering species has been investigated at the operational potential of $0.5 \mathrm{~V}$ in $0.05 \mathrm{M}$ phosphate buffer at $\mathrm{pH}$ 7. The current responses of the biosensors to $1.0 \mathrm{mM}$ 
glucose were measured under the existence of various interfering species at concentrations close to their physiological levels. Sodium oxalate $(0.2 \mathrm{mM})$, urea $(1.0 \mathrm{mM})$, and glutamate $(0.1 \mathrm{mM})$ did not produce any observed interference on the responses of the glucose biosensor based on the zirconia/ Nafion composite film. However, the presence of ascorbic acid $(0.1 \mathrm{mM})$ and uric acid $(0.5 \mathrm{mM})$ caused an increase in the responses of the biosensor based on the zirconia/Nafion composite by about $26 \%$ and $22 \%$, respectively. In contrast, the pure zirconia-based biosensor without the incorporation of Nafion showed increased responses by about $206 \%$ and $237 \%$ in the presence of ascorbic acid $(0.1 \mathrm{mM})$ and uric acid $(0.5 \mathrm{mM})$. This result indicates that the presence of Nafion in the zirconia/Nafion composite film greatly diminishes the interferences from ascorbic acid and uric acid because of the negatively charged sulfonate $\left(\mathrm{SO}_{3}{ }^{-}\right)$groups in Nafion, thus it makes the negatively-charged interfering species unapproachable to electrode surface.

The long-term storage stability was studied over a certain period of time by monitoring its current to the injection of $1.0 \mathrm{mM}$ glucose solution with intemittent usage (every 1-2 days). The biosensor based on the zirconia/Nafion retained its activity about $90 \%$ of its initial value after 4 weeks. The stability of the present biosensor based on the $\mathrm{ZrO}_{2} / \mathrm{Nafion}$ composite film is much better than that of silica/Nafion composite-based biosensor, and also comparable to the titania/Nafion composite-based biosensor ( $82 \%$ of initial response retained after 4 months). ${ }^{25}$ Further study to enhance the long-term stability of the biosensor is underway.

\section{Conclusions}

A new sol-gel-derived $\mathrm{ZrO}_{2} / \mathrm{Nafion}$ composite film was used as an encapsulation matrix to fabricate an amperometric glucose biosensor. The performance of the resulting glucose biosensor can be tuned by controlling the water content in the acid-catalyzed hydrolysis of the sol-gel stock solution and also by controlling the ratio of $\mathrm{ZrO}_{2}$ to Nafion in the composite film. Because of the increased pore size of the zirconia/Nafion composite film, the resulting biosensor exhibited relatively faster response time (less than $5 \mathrm{~s}$ ) and higher sensitivity than those obtained with the biosensors based on both pure Nafion and pure $\mathrm{ZrO}_{2}$ film. In addition, since the Nafion polymer has negatively charged surface, the sol-gel derived $\mathrm{ZrO}_{2} / \mathrm{Nafion}$ composite matrix showed diminished interferences from ascorbic acid and uric acid. Furthermore, the $\mathrm{ZrO}_{2} / \mathrm{Nafion}$ composite matrix can be easily prepared in comparison to other composites based on sol-gel inorganic/synthetic organic polymers. ${ }^{32}$ Therefore, the $\mathrm{ZrO}_{2} / \mathrm{Nafion}$ composite is an attractive matrix for the encapsulation of enzyme to fabricate biosensors and thus could be extensively used for the encapsulation of other biomolecules.

Acknowledgements. This work was financially supported by the Korea Science and Engineering Foundation through the Center for Bioactive Molecular Hybrids (CBMH) and Nano R\&D program.

\section{References}

I. Hench, L. L.; West, J. K. Chem. Rev. 1990, 90, 33.

2. Dave, B. C.; Dunn, B.; Valentine, J. S.; Zink, J. I. Anal. Chen. 1994. $66.1120 \mathrm{~A}$.

3. Lev, O.; Tsionsky, M.; Rabinovich, L.; Glezer, V.; Sampath, S.; Pankratov, I.; Jun, J. Anal. Chem, 1995, 67, 22A.

4. Lin, J.; Brown, C. W. Trends Anal. Chem. 1997, 16, 200.

5. Anvir, D.; Braun, S.; Lev, O.; Ottolenghi, M. Chent. Mater. 1994. 6,1605 .

6. Avnir, D. Acc. Chem. Res. 1995, $28,328$.

7. Wang, J. Anal. Chim. Acta 1999, 399, 21.

8. Walcarius, A. Chem, Mater $2001,13,3351$.

9. Gill, J. Chem. Mater 2001, 13, 3404.

10. Lee, S.-M.; Lee, W.-Y. Bill. Korean Chen. Soc. 2002, 23 , 1169.

11. Topoglidis, E.; Cass, A. E. G.; Gilardi, G.; Sadeghi, S.; Beaumont, N.; Durrant, J. R. Anal. Chem. 1998, 70,511l.

12. Topoglidis, E.; Cass, A. E. G; O'Regan, B.; Durrant, J. R. $J$. Electroanal. Chem, 2001, 5/7, 20.

13. Yu, J.; Ju, H. Anal. Chem. 2002, 74, 3579.

14. Yu. J.: Liu, S.; Ju. H. Biosents. Bioelectron. 2003, 19. 401.

15. Liu, Z.; Liu, B.; Zhang, M.; Kong, J.; Deng. J. Anat. Chint Acta 1999, 302, 135 .

16. Liu, Z.; Liu, B.; Kong, J.; Deng, J. Anal. Chem, 2000, 72, 4707.

17. Liu, B.; Cao, Y.; Chen, D.; Kong, J.; Deng, J. Anal. Chim. Acta 2003, 478,59.

18. Yang, Y.; Yang. H.; Yang. M.; Liu, Y.; Shen, G.; Yu, R. Anol. Chint Acta 2004, 525, 213.

19. Zhu, N.; Zhang, A.; Wang. Q.; He, P.; Fang, Y. And. Chim. Acta 2004, 510, 163 .

20. Dobson, K. D.; McQuilan, A. J. Langmim 1997, 13, 3392.

21. Fang, M.; Kaschak, D. M.; Sutorik, A. C.; Mallouk, T. E. J. Am. Chent. Soc. 1997, 119, 12184.

22. Wang, J.; Pamidi, P. V. A.; Jiang, M. Anal. Chim. Acta 1998, 360 , 171 .

23. Dong, S.; Kuwana, T. J. Electrchem. Soc, 1984, 131,813 .

24. Kim, M.-A.; Lee, W.-Y. Anal. Chim. Acta $2003,479,143$.

25. Choi, H. N.; Kim, M. A.; Lee, W.-Y, Anal. Chim, Acta 2005, 537 , 179.

26. Zhang, Z; Liu, H.; Deng. J. Anal. Chem. 1996, 68, 1632.

27. Wang, J.; Park, D. S.; Pamidi, P. V. A. J. Electroanal. Chem. 1997. 434,185 .

28. Chut, S. L.; Li, J.; Tan, S. N. Analyst 1997, 122, 1431.

29. Chen, X.; Cheng, G; Dong, S. Anatyst 2001, I26, 1728.

30. Lee, W.-Y.; Lee, K. S.; Kim, T.-H.; Shin, M.-C.; Park, J.-K. Electroantatys is 2000, 12,78 .

31. Karyakin, A. A.; Karyakina, E. K.; Gorton, L.; Bobrova, O. A.; Lukachova, L. V.; Gladilin, A. K.; Lesashov, A. V. Anal. Chem. $1996,68,4335$.

32. Wang, B.; Li, B.; Deng Q.; Dong, S. Anal. Chem, 1998, 70, 3170 .

33. Quan, D.; Kim, Y.; Shin, W. J. Electroanal. Chem. 2004, 561, 181.

34. Heider, G H.; Sasso, S. V.; Huang, K.-M.; Yacynych, A. M.; Wieck, H. J. Anal. Chem. 1990, 62, I106.

35. Chen, X.; Dong \$. Biosens. Bioelectron, 2003, $18,999$.

36. Carr, P. W.; Bowers, L. D. Innobilized Enzzmes in Antabtical and Chinical Chenistry; Wiley: New York, 1980; pp 26-30.

37. Yamanaka, S. A.; Nishida, F.; Ellerby, L. M.; Nishida, C. R.; Dunn, B.; Valentine, J. S.; Zink, J. I. Chem. Mater, 1992, 4, 495.

38. Wang J.; Pamidi, P. V.; Park, D. S. Anal. Chem. 1996, 68, 2705 . 